\title{
The Pre-Service Biology Teacher Readiness in Blended Collaborative Problem Based Learning (BCPBL)
}

\section{Bowo Sugiharto}

Department of Biology Education, Faculty of Teacher Training and Education, Universitas Sebelas Maret, Indonesia, bowo@fkip.uns.ac.id

\section{Aloysius Duran Corebima}

Prof., Biology Department, Faculty of Mathematics and Natural Science, Universitas Negeri Malang, Indonesia, durancorebima@gmail.com

\section{Herawati Susilo}

Biology Department, Faculty of Mathematics and Natural Science, Universitas Negeri Malang, Indonesia, herawati.susilo.fmipa@um.ac.id

\section{Ibrohim}

Biology Department, Faculty of Mathematics and Natural Science, Universitas Negeri Malang, Indonesia, ibrohim.fmipa@um.ac.id

This research aims at investigating the readiness level of pre-service biology teacher to follow Blended Collaborative Problem Based Learning (BCPBL) model class. This research also aims at investigating the differences in the readiness level of pre-service biology teachers in the BCPBL class due to the semesters differences. The participants were randomly selected from the students in semester 2, 4, 6, and 8 of Biology Education Study Program in Indonesia. From the total population of 750 students, 27 students, 24 students, 29 students, and 21 students were selected from the 2nd, 4th, 6th, and 8th semester students respectively. The instrument used in this research was the questionnaire modified from the one developed by Xiong et al. (2015). The reliability of the questionnaire had been tested and obtained a reliability index of 0.893 . The data obtained were analyzed descriptively and followed by using one-way analysis of variance (ANOVA). Based on the results of this research it is concluded that in general pre-service biology teacher have a high level of readiness to follow the BCPBL class. Semester differences do not cause significant differences in the level of students' readiness to follow BCPBL model.

Keywords: blended collaborative problem-based learning (BCPBL), pre-service biology teacher, semester differences, students' readiness, biology

Citation: Sugiharto, B., Corebima, A. D., Susilo, H., \& Ibrohim. (2019). The Pre-Service Biology Teacher Readiness in Blended Collaborative Problem Based Learning (BCPBL). International Journal of Instruction, 12(4), 113-130. https://doi.org/10.29333/iji.2019.1248a 


\section{INTRODUCTION}

Problem Based Learning (PBL) is a learning model that facilitates meaningful learning. It was originally introduced to medical students in the early 1950s (Tan, 2003). This learning model puts students at the center of learning processes that aim to integrate learning and practice (Alavi, 2002). This integration is characterized by the presence of case problems or scenarios so that students can define their own learning objectives (Wood, 2003). This learning process becomes more meaningful for students. In addition, to facilitate meaningful learning, PBL also develops students' complex skills and learning independence (Vidergor \& Krupnik-Gottlieb, 2015). Besides, PBL has been widely implemented in other fields of learning, and it had a positive effect.

There have been many research reports on the positive effects of PBL learning model. For example, PBL has a positive effect on the development of students' metacognition (Downing, Kwong, Chan, Lam, \& Downing, 2009); it has a significant effect on the ability to evaluate arguments in low academic ability students (Belland, Glazewski, \& Richardson, 2010). Collaborative learning is also reported to occur in PBL learning, and collaborative learning is considered to be more important in determining students' achievement than the learning activity itself (Yew \& Schmidt, 2011). The other positive effects of PBL include: improving learning achievements and positive beliefs (Tarhan \& Acar-Sesen, 2013), as well as developing students' creativity (Siew, Chong, \& Lee, 2015; Tan, 2009). This means that PBL has the potential to develop students' competencies.

One of the competencies that pre-service biology teachers need to train is the pedagogical competence. The important pedagogic competence of the biology teachers is their biology teaching skills in accordance with the nature of biology as a science. In this regard, problem-based learning enhances pedagogical competencies, especially the problem-solving skills, linking knowledge with everyday life, and providing permanent learning (Balim et al., 2014). The increase of the competence possibly occurs because of the increase of metacognitive awareness (Gassner, 2009), the increase of oral communication skills (Wahyudi, Sugiharto, \& Widoretno, 2015), and the increase of responsibility (Balim et al., 2014). In addition, the role of PBL in improving competence is supported by the potential of PBL in training critical thinking skills, which are the higher order thinking skills needed in the 21st century (Tan, 2004).

The other 21 st century skills that professional teacher candidates need to possess is Information, Communication, and Technology (ICT) skills. All academicians and educator candidates need to optimize their ICT skills to support the didactic and pedagogical potential in the classroom, as well as to support an integrated approach to pedagogy, literacy and digital knowledge (Montoro, Hinojo-Lucena, \& Sánchez, 2015). The ICT skills will encourage the development of communication skills, information literacy, and ICT literacy especially by using blended learning (Zurita, Hasbun, Baloian, \& Jerez, 2015). In this rapid information and communication era, it is essential to train not only reading, writing, and computing skills, but also the 4Cs skills, namely creativity, communication, collaboration, and critical thinking (Keane, Keane, \& Blicblau, 2014) through the change of education world with ICT (Kanematsu \& Barry, 
2016). Traditional learning should be introduced with the use of ICT to improve the quality of education (Plessis, 2015).

The utilization of technology, especially the internet, has entered the world of education. The development of technology has raised anxieties as well as new opportunities in the world of education, such as increased learning process, customization of students based on individual needs in learning, as well as increased $21^{\text {st }}$-century skills (OECD, 2010). The internet has been utilized in the education world not only as media, means of information, administrative purposes but also as a learning tool, for example, the Blended Collaborative Problem Based Learning (BCPBL) model. ICT has transformed the teachers' teaching strategies, students' learning strategies, learning scope, and it even has become a significant necessity in learning, as a tool to know the current issues in learning, and to provide new possibilities in learning (Pritchard, 2007). An example of the utilization of ICT is the use of Web 2.0 as a collaborative work tool in learning that helps teachers to evaluate the contribution of each student in completing tasks and provide fair and open assessments (Malinina, 2016). The use of ICT in the world of education has become an important factor that pre-service biology teachers need to prepare, as it becomes one of the indicators of teachers' readiness in carrying out their duties as biology teachers. This factor can be seen from their readiness in participating in the BCPBL class, which is a learning model that involves the use of ICT.

In this information era, students have been very familiar with the internet. Students are generally accustomed to using the internet for various purposes both academic and nonacademic purposes. Among students, the use of the internet for non-academic activities, for example, is indicated by the ownership of social network accounts on average of 4 accounts (Sugiharto, 2015) which are dominated by Facebook account, and the remaining is other social networking accounts (Sugiharto, Corebima, Susilo, \& Ibrohim, 2016). The internet for academic purposes has been widely used, for example, the use of e-learning in the teaching and learning activities, which is also done by senior high school students (Badri, Al Rashedi, Yang, Mohaidat, \& Al Hammadi, 2016). The use of the internet by university students, such as, for searching for references (Ribeiro, Severo, \& Ferreira, 2016) is commonly done, including in Malaysia (Gan \& Balakrishnan, 2014). In many parts of the world, the learning with student-centered pedagogy has been supported by technology (Nguyen \& Williams, 2016). In addition, university students also use the internet for communicating with their lecturers via email (Kim et al., 2016; Sugiharto, 2015; Sugiharto et al., 2016). The other involvement of students in utilizing the internet is in blended learning.

Blended learning is a blend of face-to-face learning and online learning by utilizing ICT. Blended learning can combine the advantages of the online learning method and the advantages of some aspects of face-to-face learning (Akkoyunlu \& Soylu, 2008). Blended learning as a learning model and a learning media by utilizing Moodle application supports students' independent learning. Blended learning has been implemented with a variety of designs, and it has shown positive results to be considered in the learning process (Alebaikan \& Troudi, 2010). The implementation of blended learning supports the learning process that can combine physical and virtual sources 
(virtual). Blended Learning provides what scaffolding needs, which effectively combine face-to-face and online learning (Bonk \& Graham, 2004). If Blended Learning is implemented, it will authentically encourage independent learners (Ark, Hudson, \& Baugh, 2014). The implementation of Blended Learning utilizes Information and Communication Technology (ICT). The utilization of ICT has added values to make the learning process more interesting, more efficient, and more effective in improving the students' competence (Wijaya, 2007). In Blended Learning, the drawback of online learning can be covered with the advantages of face to face learning (So \& Brush, 2008).

One way to implement Blended Learning is by using Blended Collaborative Problem Based Learning (BCPBL), in which the syntax of this learning model has the characteristics as described in the research methodology. BCPBL is a learning model developed by the researcher. It is a PBL platform learning model which is done by implementing collaborative efforts and integrating face-to-face learning and online learning. As a learning model, BCPBL has a particular syntax. It uses real-life problems which the students attempt to find and formulate the solution. Moreover, the collaboration occurs not only during the face to face session but also during the online session. The students can conduct discussions synchronously and asynchronously, and they can cooperate to complete the learning tasks. Therefore, before BCPBL is implemented, information about the students' readiness for the BCPBL class is needed.

The students' readiness in class (BCPBL) should be considered before the learning begins. The readiness of the pre-service biology teachers is a determining factor for the success of the implementation of BCPBL learning model. If the students have already been accustomed to working in groups, solving problems presented in lectures, using the internet especially social networking, does it also mean that they have a high level of readiness to follow the BCPBL learning model. This can be assessed from awareness, culture, technology, pedagogy, and content (Omoda-Onyait \& Lubega, 2011). Specifically, it also needs to consider about the technological access skills, online relationship motivation, online reading, online audio conversations, online group discussions, and views of importance for success (Watkins, Leigh, \& Triner, 2004). An understanding of the students' readiness for online learning is required (Dray, Lowenthal, Miszkiewicz, Ruiz-Primo, \& Marczynki, 2011) to support the implementation of online learning, including the BCPBL learning. Moreover, BCPBL whose elements are utilizing the internet, the teachers' readiness and students' readiness becomes an important aspect (Gan \& Balakrishnan, 2014). Referring to the concepts proposed by Xiong, So, \& Toh (2015), the students' readiness in BCPBL learning includes motivation for BCPBL, prospective behavior that supports the implementation of BCPBL, and the online learning skill. Therefore, in this research, the students' readiness in following the BCPBL class is assessed based on these three factors.

\section{Purpose of The Study}

It is important to investigate the students' readiness so that the BCPBL learning can be implemented successfully and it does not find any significant obstacles. The success of the implementation of $\mathrm{BCPBL}$ learning is determined by motivation for BCPBL 
learning, prospective behavior that supports the implementation of BCPBL learning, and the students' online learning skills. The online learning skills, as applied in the BCPBL model, are largely determined by the readiness of the students themselves (Watkins et al., 2004). Differences in students' semester certainly cause the students' various learning experiences. Similarly, differences in the length of time that the students have learned also cause differences in the experience of using ICT. However, will this cause differences in students' readiness for BCPBL classes? This question will be examined in this study. Does the students' semester cause differences in the students' readiness for BCPBL learning?

\section{METHOD}

\section{General Background of the Research}

This research was conducted in March-April 2016. This was exploratory survey research involving 101 participants, who were randomly selected from the $2^{\text {nd }}, 4^{\text {th }}, 6^{\text {th }}$, and $8^{\text {th }}$-semester students. Viewed from gender, the participants consisted of 83 females and 18 males. The participants of this research were the students of biology education study program of the Teacher Training and Education Faculty at Universitas Muhamadiyah Surakarta in Indonesia. The total number of selected students was 27, 24, 29 , and 21 students respectively. They took various subjects referring the curriculum applied in Biology Education. The referred curriculum contained several subjects either general subjects or those directly related to biology competence as well as biology education competence.

The teaching process following the syntax of BCPBL learning model is presented in Table 1.

Table 1

Stages and Explanation of the Syntax of BCPBL Learning Model Syntax

\begin{tabular}{|c|c|c|c|}
\hline No. & Stages & Description & Implementation \\
\hline 1 & Preparation & $\begin{array}{l}\text { The lecturer gives explanations and orientation of lecture, and forms a } \\
\text { collaborative group of students }\end{array}$ & $\begin{array}{l}\text { Face to face and } \\
\text { online }\end{array}$ \\
\hline 2 & Observation & $\begin{array}{l}\text { The collaborative groups make observations to find real learning problems } \\
\text { in Biology class in Senior high schools by focusing on the standard } \\
\text { processes in learning. }\end{array}$ & Face to face \\
\hline 3 & $\begin{array}{l}\text { Analyzing } \\
\text { problems }\end{array}$ & $\begin{array}{l}\text { The collaborative groups analyze the problems by focusing on the standard } \\
\text { processes and determining the root of the problems related to the } \\
\text { application of learning strategies, methods, or models }\end{array}$ & $\begin{array}{l}\text { Face to face and } \\
\text { online }\end{array}$ \\
\hline \multirow[t]{2}{*}{4} & $\begin{array}{l}\text { Formulating } \\
\text { solution } \\
\text { plans }\end{array}$ & $\begin{array}{l}\text { The collaborative groups formulate a solution plan to overcome the } \\
\text { problems that have been found from observations in the form of learning } \\
\text { simulation plans. }\end{array}$ & $\begin{array}{l}\text { Face to face and } \\
\text { online }\end{array}$ \\
\hline & & The groups finalize the $d r a f t$ of the solution plan collaboratively. & Face to face \\
\hline 5 & $\begin{array}{l}\text { Presenting } \\
\text { the work } \\
\text { results }\end{array}$ & $\begin{array}{l}\text { Collaborative groups share roles in learning practice simulation by applying } \\
\text { learning strategies, methods, or models to overcome the existing } \\
\text { problems. After the simulation, the group presents the actions or the } \\
\text { activities done along with the explanation of the related material. The } \\
\text { representatives of the groups upload the documentation for the } \\
\text { implementation of the simulation and the material of the presentation }\end{array}$ & $\begin{array}{l}\text { Face to face and } \\
\text { online }\end{array}$ \\
\hline 6 & $\begin{array}{l}\text { Reflection } \\
\text { and } \\
\text { evaluation }\end{array}$ & $\begin{array}{l}\text { The collaborative groups and the class conduct evaluations and reflections } \\
\text { from the observation activity until the implementation of solution actions }\end{array}$ & ace \\
\hline
\end{tabular}




\section{Instruments and Procedures}

The instruments used in this research were adapted from the instruments developed by Xiong et al. (2015). This instrument examined the readiness of students to attend $B C P B L$ class based on three aspects, including the aspect of collaboration and problembased learning motivation, the aspect of prospective behavior that supports the implementation of BCPBL, and the aspect of online learning ability. The aspects of motivation consist of 15 items which reveal four points, namely interest, perception, self-efficacy, and reinforcement for problem-based learning that has been adapted to the BCPBL learning model and tested for its reliability. The aspect of prospective behavior consisted of 15 items which attempted to reveal communication, collaborative problem solving, self-management, and conflict resolution behavior. While the aspect of online learning ability consisted of 9 items which attempted to reveal the skills and comfort in using information, communication, and technology. In summary, the instruments used for revealing the readiness of the students are presented in Table 2 below.

Table 2

Detailed Items of each Aspect of Student Readiness Instrument in BCPBL Class

\begin{tabular}{lll}
\hline Aspects & Subaspect & Number of items \\
\hline Motivation & Interests & 4 \\
& Perception values & 4 \\
& Self-efficacy & 4 \\
& Reinforcement & 3 \\
\hline Prospective & Communication & 6 \\
behavior & Collaborative problem solving & 4 \\
& Self-management & 3 \\
& Conflict resolution behavior & 2 \\
\hline Online learning & Skills in using ICT & 5 \\
ability & Comfort in using ICT & 4 \\
\hline
\end{tabular}

Modified from Xiong et al. (2015)

\section{Data Analysis}

The data obtained were then descriptively analyzed. Descriptive statistics were used to reveal the average and standard variance of each aspect. Furthermore, the average of the students' readiness of each semester was discussed based on the applied criteria and used in this research site, as shown in Table 3.

Table 3

Score Conversion and Reference Criteria

\begin{tabular}{lll}
\hline Final score & Letter score (Qualification) & Number score (Scale 4.0) \\
\hline $77 \leq$ score $\leq 100$ & A & 4,0 \\
$70 \leq$ score $<77$ & AB & 3.5 \\
$63 \leq$ score $<70$ & B & 3.0 \\
$56 \leq$ score $<63$ & BC & 2.5 \\
$50 \leq$ score $<56$ & C & 2.0 \\
$35 \leq$ score $<50$ & D & 1.0 \\
$0 \leq$ score $<35$ & E & 0.0 \\
\hline
\end{tabular}

Source: Universitas Muhammadiyah Surakarta (2010) 
To reveal if there was a difference in the readiness of students in the BCPBL class, caused by the students' semester, one-way analysis of variance (ANOVA) was performed. Before the ANOVA test was performed, assumption tests were performed. The assumption tests were a normality test and a homogeneity test. The normality test was done by using Kolmogorov-Smirnov test with Lilliefors correction, and the homogeneity test was done by using Levene's test. After the data was confirmed as normally distributed and had homogeneous variance, it was analyzed by with the ANOVA test. All the statistical tests (the normality, homogeneity, and ANOVA tests) were done with the assistance of IBM SPSS Statistics 22 computer program.

\section{FINDINGS}

\section{The Readiness Level of Pre-Service Biology Teacher in BCPBL Class}

The readiness of students in BCPBL class was depicted in descriptive statistics. The mean, standard deviation, standard error, minimum score, and the maximum score of the readiness of semester 2 , semester 4 , semester 6 and semester 8 students are presented in Table 4.

Table 4

Descriptive Statistics of Students' Readiness in BCPBL Class based on Semester

\begin{tabular}{lllllll}
\hline Semester & N & Mean & Std. deviation & Std. error & Minimum & Maximum \\
\hline SMT_2 & 27 & 76.64 & 5.22 & 1.00 & 65.38 & 87.82 \\
SMT_4 & 24 & 79.38 & 6.14 & 1.25 & 67.31 & 93.59 \\
SMT_6 & 29 & 76.26 & 4.92 & .91 & 65.38 & 91.03 \\
SMT_8 & 21 & 78.66 & 4.54 & .99 & 73.08 & 86.54 \\
Total & 101 & 77.60 & 5.33 & .53 & 65.38 & 93.59 \\
\hline
\end{tabular}

Furthermore, based on the criteria as listed in Table 3, the average of the students' readiness levels is described in the categories as listed in Table 5.

Table 5

Mean Score of Readiness in BCPBL and Its Conversion into Reference Criteria

\begin{tabular}{lll}
\hline Semester & Mean of readiness & Letter score (Qualification) \\
\hline SMT_2 & 76.64 & AB \\
SMT_4 & 79.38 & AB \\
SMT_6 & 76.26 & AB \\
SMT_8 & 78.66 & A \\
\hline
\end{tabular}

The Effect of Semester on Readiness of Pre-Service Biology Teacher in BCPBL Class

Furthermore, it will be revealed whether or not the difference in the semester has an effect on the readiness of students in following the BCPBL class. This is important to ensure that the learning model can be accepted by all pre-service biology teacher as the population of this research. Therefore, empirical testing using ANOVA test was carried out, which was preceded by the assumption tests, namely the normality and the homogeneity test. A summary of the results of the normality test using KolmogorovSmirnov is presented in Table 6. 
Table 6

Summary of Normality Test using Kolmogorov-Smirnov

\begin{tabular}{lllll}
\hline & \multirow{2}{*}{ Semester } & \multicolumn{3}{l}{ Kolmogorov-Smirnov $^{\mathrm{a}}$} \\
\cline { 3 - 5 } & & Statistic & df & sig. \\
\hline Readiness & SMT_2 & .072 & 27 & $.200^{*}$ \\
& SMT_4 & .127 & 24 & $.200^{*}$ \\
& SMT_6 & .120 & 29 & $.200^{*}$ \\
& SMT_8 & .176 & 21 & .087 \\
\hline
\end{tabular}

*. This is a lower bound of the true significance.

a. Lilliefors Significance Correction

Moreover, a summary of the homogeneity test results of the students' readiness using Levene's Test is presented in Table 7.

Table 7

Summary of Homogeneity Test Results using Levene's Test

\begin{tabular}{llll}
\hline $\mathrm{F}$ & df1 & df2 & sig. \\
\hline .803 & 3 & 97 & .495 \\
\hline
\end{tabular}

a. Design: Intercept + Semester

Tests the null hypothesis that the error variance of the dependent variable is equal across groups.

Table 6 and Table 7 show that the samples were obtained from a population with normal distribution and homogeneous variance. Thus, based on the results of the two assumption tests, the analysis can be continued with the hypothesis test using ANOVA.

A summary of the results of ANOVA test on the readiness of students in BCPBL class is presented in Table 8.

Table 8

Summary of ANOVA Test Results on the Students' Readiness based on Semester

\begin{tabular}{llllll}
\hline Source & Type III Sum of Squares & df & Mean square & F & sig. \\
\hline Corrected model & $176.956^{\mathrm{a}}$ & 3 & 58.985 & 2.147 & .099 \\
Intercept & 601255.547 & 1 & 601255.547 & 21880.790 & .000 \\
Semester & 176.956 & 3 & 58.985 & 2.147 & .099 \\
Error & 2665.433 & 97 & 27.479 & & \\
Total & 611077.398 & 101 & & & \\
Corrected total & 2842.390 & 100 & & & \\
\hline a. R Squared $=.062$ (Adjusted R Squared $=.033$ ) & & & &
\end{tabular}

Table 8 shows that there is not any difference in the readiness of students related to the implementation of BCPBL class among different semesters. Semester difference does not have a significant effect on the readiness of students to follow a class using BCPBL model.

\section{DISCUSSION}

\section{The Readiness Level of Pre-Service Biology Teacher in BCPBL Class}

Based on the average of students' readiness in the BCPBL class, most students in each semester were in category $\mathrm{A}$ and $\mathrm{AB}$. The details of the category of each semester based 
on the assessment criteria used in UMS were semester 2 included in category $\mathrm{AB}$, semester 4 included in category A, semester 6 included in category AB, and semester 8 included in category A. This means that the readiness of students to follow the BCPBL class was high. Therefore, the BCPBL model is expected to be able to be implemented in the classes in biology education without any difficulties.

The success of the implementation of BCPBL model is supported with two important things, namely the students' experience in attending classes and the students' experience in using ICT. The experience in attending classes was obtained from some lecturers teaching them and various learning models they have experienced during their study. Meanwhile, the students' experience in using ICT is one manifestation of the millennial generation that is generally already familiar with computers, internet, and gadgets. Therefore, this millennial generation is early to recognize and use ICT and generally can adapt quickly to it. All these factors simultaneously improve the status of mental function so that the readiness of students to follow BCPBL classes is formed.

The readiness of students to follow the BCPBL class becomes an important thing to be considered. When the students are ready to follow the learning and accept the concept is often referred to as a teachable moment, which means that the students or groups of students are at higher mental function (Slavin, 2006). Readiness will bring up the courage to do and create a new thing (Tan, 2009), moreover, when it is supported by institutions and cultural change. Institutional support and cultural change are important in determining students' readiness (Boitshwarelo, 2009).

\section{The Effect of Semester on Readiness of Pre-Service Biology Teacher in BCPBL Class}

The findings of this research differ from those of the research conducted by Pillay, Irving, \& Tones (2007) that the online learning readiness of older students is lower than that of the younger students due to the lower computer technical skills and self-efficacy. In contrast, these research results are in line with the researches revealing that age does not have a correlation with students' readiness (Heo \& Han, 2018). That differences in students'semester do not have an effect on the students' readiness becomes one of the elements that support the implementation of 'education for all' (Omoda-Onyait \& Lubega, 2011). Seniority and age are not the factors determining the students' readiness for online learning, but emotional intelligence is influential (Buzdar, Ali, \& Tariq, 2016).

The readiness of students in the BCPBL class is better due to students' ability to learn by utilizing technology and possessing the technical skills required to use technology in teaching and learning activities (Anuar, Zakaria, Noor, \& Othman, 2016). Furthermore, to support the implementation of BCPBL, the institutions need to encourage the students to be successful online learners by promoting a balance between pedagogy, students' readiness, and accessibility (van Rooij \& Zirkle, 2016). Certainly, the students' readiness involves three dimensions: (a) motivation for collaborative learning, (b) prospective behavior for collaborative learning and (c) online learning skill (Xiong et al., 2015) in PBL platform. 


\begin{abstract}
Motivation
Motivation is an element that stimulates the psychological tendency to engage in collaborative learning both in direct learning and in online learning within the PBL platform. The elements that stimulate this psychological tendency include both extrinsic and intrinsic aspects (Xiong et al., 2015). Intrinsic motivation is the best predictor of performance quality, whereas extrinsic motivation is the best predictor of performance quantity (Wijsman, Saab, Schuitema, van Driel, \& Westenberg, 2019). The extrinsic aspect is influenced by the learning environment, while the intrinsic aspect arises from within one's individual.
\end{abstract}

In today's information era, the learning environment can encourage social interaction and generate motivation especially for early semester students (Noyens, Donche, Coertjens, van Daal, \& van Petegem, 2019), so that they can be as good as the higher semester students. Motivation can grow from social interaction. The effect of social interactions, such as the habit of working together in learning tasks and the habit of interacting with friends who use ICT, can generate motivation to do something related to it. Thus, social interaction affects interactive e-learning and the application of collaborative media (Cheng, 2018).

The existence of computer-supported collaboration can be the main attraction for students regardless of their semesters so that it increases their motivation to learn. Computer-supported collaborative learning (CSCL) in the BCPBL model has the potential to improve the quality of learning from the aspects of students' interaction, motivation, and understanding (Yang, Ghislandi, \& Dellantonio, 2018). Improving motivation regulation and adopting independent-learning strategies can be academically useful because students who are accustomed to online learning generally tend to be more adaptive (Broadbent \& Fuller-Tyszkiewicz, 2018) regardless of seniority.

Students' intrinsic motivation in online collaborative learning is not influenced by students' seniority or semesters, but it is rather influenced by the students' attitude toward technology that contributes to the emergence of attitudes to love the use of advanced technology, confidence in using technology, and reduced technological anxiety (Shonfeld \& Magen-Nagar, 2017). Motivation is related to passion. A harmonious passion contributes to students' knowledge management and self-regulation in a learning context involving online learning elements (Yeh \& Chu, 2018). Motivation is also suspected to affect students' performance especially during a small group discussion on PBL learning (Dolmans \& Schmidt, 2006).

Not only affects students' readiness in learning, but motivation also becomes a factor that can predict students' readiness in learning (Heo \& Han, 2018). Moreover, motivation also has a contribution toward success and satisfaction in online learning at universities (Kauffman, 2015). Motivation also becomes a factor determining students' persistence and improves students' behavior in the classroom (Lucey, 2018).

\title{
Prospective behavior that supports BCPBL readiness
}

Prospective behavior in collaboration and in the use of ICT can minimize the negative effect of overload information if it is sustained with metacognitive competence. With 
their metacognitive competence, students are able to perform internal management of their own cognitive load (Chen, Pedersen, \& Murphy, 2011). Metacognitive skills will direct a person's behavior in dealing with various situations to become positive activities.

The prospective behavior that supports the students' readiness to participate in the BCPBL learning model includes at least the behaviors that involve the habits to use ICT and collaborative behavior. The results of this research indicate that the two types of behavior are not significantly different which is caused by the differences in the students' semesters. The behavior of using ICT facilitates the learning process which utilizes the internet. Collaborative behavior concerns with social skills to achieve common goals. Both types of these behaviors framed in PBL platform learning have a contribution in shaping the students' readiness in following the BCPBL class.

The behavior of using ICT that becomes a student's habit in the information era has the potential to support students' readiness in BCPBL class. This behavior affects digital readiness, which is a manifestation of various digital capabilities with different perspectives and characteristics (Hong \& Kim, 2018). A culture of using the internet with positive attitudes has a contribution on building communication and collaboration outside the classroom via online (Malinina, 2016). In behavior, habit shapes the experience. The experience factor has an effect on the readiness of teacher candidates on integrating technology especially ICT (Sun, Strobel, \& Newby, 2017) in collaborative online learning, especially if the behavior shaping the experience is facilitated by the institution (van Rooij \& Zirkle, 2015).

The collaborative culture obtained in the previous learning in the form of instructional interventions contributes to the students' readiness in attending a class (Bonner \& Thomas, 2017). The instructional intervention is especially obtained from the learning in all semesters which requires problem-solving in groups. Beginning from the responsibility to solve problems in their learning, the students establish communication and collaboration despite semester differences. Thus, it further confirms that PBL learning platforms implemented with collaborative online learning is solely determined by students' habits regardless of their semester differences (VanOostveen, Desjardins, \& Bullock, 2018). Such student conditions will reduce technical difficulties in its implementation. Thus, students' behavior affects not only students' readiness but also collaborative learning results (Winters \& Alexander, 2010).

Students' readiness to attend BCPBL model is also seen from their readiness to undergo PBL learning pattern, especially by paying attention to basic knowledge, maturity, needs, and motivation (Tan, 2003). Readiness also refers to cognitive competence, both on knowledge of relevant facts and on knowledge of the use of thought and reasoning for decision-making or conclusions from what has been learned and the application of common procedures to adapt to new situations (Griffin \& Care, 2015). The students' ability from the PBL aspects is obtained from the learning in biology education related to laboratory work and problem-solving based learning. In summary, prospective behavior concerns with communication skills, problem-solving, and self-management and conflict resolution (Xiong et al., 2015). 


\section{Online learning skills}

There has been a lot of changes in the academic life of the students in this information era compared to that of the previous era. Moreover, the changes do not only occur after entering universities, but it has already occurred since secondary schools. The students have been frequently assigned to search for online references, to use certain software, to complete and to send tasks using email, to complete multimedia tasks, and so on (Hong \& Kim, 2018). This concerns with the capability of using technology, both basic skills of technology use, ease of access, use of technology, and interaction with technology (Dray et al., 2011).

An important factor of online learning readiness is the technical skills of ICT use (Smith, 2005). This technical skill does not depend on the student's age or level in classes/lectures. Other research results have suggested that the level of online learning readiness predicts academic motivation. Academic motivation is effective in improving online learning (Horzum, Kaymak, \& Gungoren, 2015).

The opportunity to engage in online collaborative activities is open to all students regardless of their semester differences. Online collaborative activities are now facilitated by web 2.0 (Muuro, Wagacha, Kihoro, \& Oboko, 2014) as what has been commonly used by students in using social media. Collaborative learning which occurs at not only classrooms but also online will be more optimal if the institution ensures the availability of adequate bandwidth (Muuro et al., 2014) so that all students from various semester can utilize it. The success of the implementation of Blended Collaborative Problem Based Learning begins from the students' readiness. The students' readiness is influenced by their talent in using ICT (Taradi, Taradi, Radić, \& Pokrajac, 2005). Therefore, like the older semester students, it is natural that the younger semester students are also ready to attend BCPBL class.

In summary, the talent of online learning includes two aspects, namely: technical skills and comfort level in online learning (Xiong et al., 2015). Technical skills are mostly honed through the use of the internet in everyday life either related to academic and nonacademic interests. The comfort in online learning is also increasingly fostered along with the high frequency of online learning experiences (Leh, 2000) and it is positively correlated with the performance to be generated (Bergin \& Reilly, 2005). Both of the technical skills and the comfort of online learning are not correlated with seniority or students' semester.

\section{CONCLUSION}

This research concludes that the students of Biology Education have a high readiness (in category $\mathrm{A}$ and $\mathrm{AB}$ ) to participate in a class implementing the BCPBL learning model. The integration between online learning and face-to-face learning, which are based on problem-based learning and collaborative activities, becomes a prospective effort to be implemented in the classroom learning at Biology Education because the students have high readiness. 
In addition, this research also concludes that there is not any difference in the readiness of different semester students. The student semester level/seniority does not affect the students' readiness to follow BCPBL class. The learning experience in previous classes/lectures and the students' skills in using the internet obtained from daily experience become the support of students' readiness in BCPBL classes. These experiences do not depend on the students' semester level or seniority.

\section{RECOMMENDATIONS}

Based on the results of this research, it is recommended that: 1) In implementing $\mathrm{BCPBL}$, it is not necessary to pay much attention to the students' semester level because it does not have a significant difference in students' readiness to follow BCPBL classes. 2) In order to support the students' readiness for the implementation of BCPBL, institutions, in this case, the universities, need to facilitate the ease of internet access such as increasing bandwidth, internet network, and policies that encourage the enforcement of BCPBL class.

\section{REFERENCES}

Akkoyunlu, B., \& Soylu, M. Y. (2008). A study of student's perceptions in a blended learning environment based on different learning styles. Journal of Educational Technology \& Society, 11(1), 183-193.

Alavi, C. (2002). Problem-based learning in a health sciences curriculum. New York: Routledge.

Alebaikan, R., \& Troudi, S. (2010). Blended learning in Saudi Universities: Challenges and perspectives. Research in Learning Technology, 18(1), 49-59. https://doi.org/10.1080/09687761003657614.

Anuar, R., Zakaria, W. Z. W., Noor, H. M., \& Othman, N. F. (2016). TPACK in VAE: A study on students' readiness to use e-learning in the teaching and learning of visual art education. In C. Y. Fook, G. K. Sidhu, S. Narasuman, L. L. Fong, \& S. B. A. Rahman (Eds.), 7th International Conference on University Learning and Teaching (InCULT 2014) Proceedings (pp. 811-822). Singapore: Springer Singapore.

Ark, T. Vander, Hudson, T., \& Baugh, J. (2014). Blended learning: Best practices for empowering students and educator. Retrieved from https://www.districtadministration.com/article/blended-learning-best-practicesempowering-students-and-educators.

Badri, M., Al Rashedi, A., Yang, G., Mohaidat, J., \& Al Hammadi, A. (2016). Students' intention to take online courses in high school: A structural equation model of causality and determinants. Education and Information Technologies, 21(2), 471-497. https://doi.org/10.1007/s10639-014-9334-8.

Balim, A. G., Turkoguz, S., Ormanci, U., Kacar, S., Evrekli, E., \& Ozcan, E. (2014). Teachers' views about problem-based learning through concept cartoons. Journal of Baltic Science Education, 13(4), 458-468. 
Belland, B. R., Glazewski, K. D., \& Richardson, J. C. (2010). Problem-based learning and argumentation: Testing a scaffolding framework to support middle school students' creation of evidence-based arguments. Instructional Science, 39(5), 667-694. https://doi.org/10.1007/s11251-010-9148-z.

Bergin, S., \& Reilly, R. (2005). The influence of motivation and comfort-level on learning to program. In 17th Workshop of the Psychology of Programming Interest Group (pp. 293-304). Sussex University.

Boitshwarelo, B. (2009). Exploring blended learning for science teacher professional development in an african context. The International Review of Research in Open and Distributed Learning, 10(4), 1-19.

Bonk, C. J., \& Graham, C. R. (2004). Handbook of blended learning: Global perspectives, local design. San Francisco: Pfeiffer Publishing.

Bonner, S. M., \& Thomas, A. S. (2017). The effect of providing instructional facilitation on student college readiness. Instructional Science, 45(6), 769-787. https://doi.org/10.1007/s11251-017-9426-0.

Broadbent, J., \& Fuller-Tyszkiewicz, M. (2018). Profiles in self-regulated learning and their correlates for online and blended learning students. Educ. Technology Research and Development, 66(6), 1435-1455. https://doi.org/10.1007/s11423-018-9595-9.

Buzdar, M. A., Ali, A., \& Tariq, R. U. H. (2016). Emotional intelligence as a determinant of readiness for online learning. International Review of Research in Open and Distributed Learning, 17(1), 148-158. https://doi.org/10.19173/irrodl.v17i1.2149.

Chen, C., Pedersen, S., \& Murphy, K. L. (2011). The influence of perceived information overload on student participation and knowledge construction in computer-mediated communication. Inst. Sci., 40(2), 325-349. https://doi.org/10.1007/s11251-011-9179-0.

Cheng, E. W. L. (2018). Choosing between the theory of planned behavior (TPB) and the technology acceptance model (TAM). Educational Technology Research and Development, 67(1), 21-37. https://doi.org/10.1007/s11423-018-9598-6.

Dolmans, D. H. J. M., \& Schmidt, H. G. (2006). What do we know about cognitive and motivational effects of small group tutorials in problem-based learning? Advances in Health Sciences Education, 11(4), 321-336. https://doi.org/10.1007/s10459-006-9012-8.

Downing, K., Kwong, T., Chan, S.-W., Lam, T.-F., \& Downing, W.-K. (2009). Problem-based learning and the development of metacognition. Higher Education, 57(5), 609-621.

Dray, B. J., Lowenthal, P. R., Miszkiewicz, M. J., Ruiz-Primo, M. A., \& Marczynki, K. (2011). Developing an instrument to assess student readiness for online learning: A $\begin{array}{llll}\text { validation study. Distance Education, 32(1), 29-47. } & \text {. }\end{array}$ https://doi.org/10.1080/01587919.2011.565496.

Gan, C. L., \& Balakrishnan, V. (2014). Determinants of mobile wireless technology for 
promoting interactivity in lecture sessions: an empirical analysis. Journal of Computing in Higher Education, 26(2), 159-181. https://doi.org/10.1007/s12528-014-9082-1.

Gassner, L. (2009). Developing metacognitive awareness-a modified model of a PBLtutorial (Unpublished bachelor thesis). Malmo University, Swedeen.

Griffin, P., \& Care, E. (Eds.). (2015). Assessment and teaching of 21 st century. Netherlands: Springer.

Heo, J., \& Han, S. (2018). Effects of motivation, academic stress and age in predicting self-directed learning readiness (SDLR): Focused on online college students. Educ. and Information Technologies, 23(1), 61-71. https://doi.org/10.1007/s10639-017-9585-2.

Hong, A. J., \& Kim, H. J. (2018). College students' digital readiness for academic engagement (DRAE) scale: Scale development and validation. The Asia-Pacific Education Researcher, 27(4), 303-312. https://doi.org/10.1007/s40299-018-0387-0.

Horzum, M. B., Kaymak, Z. D., \& Gungoren, O. C. (2015). Structural equation modeling towards online learning readiness, academic motivations, and perceived learning. Educational Sciences: Theory and Practice, 15(3), 759-770.

Kanematsu, H., \& Barry, D. M. (2016). STEM and ICT education in intelligent environments. Springer International Publishing.

Kauffman, H. (2015). A review of predictive factors of student success in and satisfaction with online learning. Research in Learning Technology, 23(1063519), 1-13.

Keane, T., Keane, W. F., \& Blicblau, A. S. (2014). Beyond traditional literacy: Learning and transformative practices using ICT. Education and Information Technologies, 21(4), 769-781. https://doi.org/10.1007/s10639-014-9353-5.

Kim, D.-H., Yoon, H. B., Yoo, D.-M., Lee, S.-M., Jung, H.-Y., Kim, S. J., ... Yim, J.-J. (2016). Etiquette for medical students' email communication with faculty members: A single-institution study. BMC Medical Education, 16(1), 1-11. https://doi.org/10.1186/s12909-016-0628-y.

Leh, A. S. C. (2000). Teachers' comfort level, confidence, and attitude. In Society for Infromation Technology \& Teacher Education International Conference (SITE). San Diego, California.

Lucey, K. (2018). The effect of motivation on student persistence in online higher education: A phenomenological study of how adult learners experience motivation in a web-based distance learning environment (Unpublished doctoral disertation). Duquesne University, USA. Retrieved from https://dsc.duq.edu/etd/1449.

Malinina, I. A. (2016). Implementing web 2.0 tools for collaborative work of learners studying English. The New Educational Review, 43(1), 104-113.

Montoro, M. A., Hinojo-Lucena, F. J., \& Sánchez, F. R. (2015). A study on ICT training among faculty members of Spanish Faculties of Education. The New Educational Review, 42(4), 27-39. 
Muuro, M. E., Wagacha, W. P., Kihoro, J., \& Oboko, R. (2014). Students' perceived challenges in an online collaborative learning environment: A case of higher learning institutions in Nairobi, Kenya. The International Review of Research in Open and Distributed Learning, 15(6), 132-160.

Nguyen, N., \& Williams, P. J. (2016). An ICT supported sociocultural approach to improve the teaching of physics. Asia-Pacific Science Education, 2(1), 1-21. https://doi.org/10.1186/s41029-016-0008-2.

Noyens, D., Donche, V., Coertjens, L., van Daal, T., \& van Petegem, P. (2019). The directional links between students' academic motivation and social integration during the first year of higher education. European Journal of Psychology of Education, 34(1), 67-86. https://doi.org/10.1007/s10212-017-0365-6.

OECD. (2010). Are the New Millennium learners making their grade? Technology use and educational performance in PISA. Eduactional research and innovation. OECD Publishing. https://doi.org/10.1787/9789264076044-en.

Omoda-Onyait G., Lubega J.T. (2011) E-learning readiness assessment model: A case study of higher institutions of learning in Uganda. In R. Kwan,, J. Fong, L. Kwok, \& J. Lam (Eds.) Hybrid Learning. ICHL 2011. Lecture Notes in Computer Science, vol 6837. Springer, Berlin, Heidelberg. https://doi.org/10.1007/978-3-642-22763-9_19.

Pillay, H., Irving, K., \& Tones, M. (2007). Validation of the diagnostic tool for assessing tertiary students' readiness for online learning. Higher Education Research and Development, 26(2), 217-234. https://doi.org/10.1080/07294360701310821.

Plessis, A. Du. (2015). Rethinking traditional science teaching through infusing ICT learning embedded by a 'learning-as-design' approach. J. of Baltic Science Education, 14(1), 4-6. Retrieved from http://www.scientiasocialis.lt/jbse/files/pdf/vol14/46.DuPlessis_JBSE_Vol.14_No.1.pdf.

Pritchard, A. (2007). Effective teaching with internet technologies: Pedagogy and practice. London: Paul Chapman Publishing.

Ribeiro, L., Severo, M., \& Ferreira, M. A. (2016). Performance of a core of transversal skills: self-perceptions of undergraduate medical students. BMC Medical Education, 16(1), 18. https://doi.org/10.1186/s12909-016-0527-2.

Shonfeld, M., \& Magen-Nagar, N. (2017). The impact of an online collaborative program on intrinsic motivation, satisfaction and attitudes towards technology. Technology, Knowledge and Learning, 1-17. https://doi.org/10.1007/s10758-017-9347-7.

Siew, N. M., Chong, C. L., \& Lee, B. N. (2015). Fostering fifth graders' scientific creativity through problem-based learning. J. of Baltic Science Educ., 14(5), 655-669.

Slavin, R. E. (2006). Educational psychology: Theory and practice. Boston: Pearson Education, Inc.

Smith, P. J. (2005). Learning preferences and readiness for online learning. Educational 
Psychology, 25(1), 3-12. https://doi.org/10.1017/CBO9781107415324.004.

So, H.-J., \& Brush, T. A. (2008). Student perceptions of collaborative learning, social presence and satisfaction in a blended learning environment: Relationships and critical factors. Computers \& Education, 51(1), 318-336.

Sugiharto, B. (2015). The profile of the utilization of information and communication technology and its potency for blended learning development in biology education department of teacher training and education faculty of UNS. In Seminar Nasional XII Pendidikan Biologi, 12, 611-617.

Sugiharto, B., Corebima, A. D., Susilo, H., \& Ibrohim. (2016). Pengembangan blended learning di pendidikan biologi FKIP UMS: Prospek dan tantangannya (Blended learning development in Biology Education Department of FKIP UMS: Its prospects and challenges). In Seminar Nasional Pendidikan dan Saintek, 865-872.

Sun, Y., Strobel, J., \& Newby, T. J. (2017). The impact of student teaching experience on pre-service teacher's readiness for technology integration: A mixed methods study with growth curve modeling. Educational Technology Research and Development, 65(3), 597-629. https://doi.org/10.1007/s11423-016-9486-x.

Tan, O. S. (2003). Problem-based learning innovation: Using problems to power learning in the 21st century. Singapore: Thomson Learning Asia.

Tan, O. S. (2004). Enhancing thinking through problem-based learning approaches: International perspectives. Singapore: Cengage Learning.

Tan, O. S. (2009). Problem-based learning and creativity. Singapore: Cengage Learning Asia Pte Ltd.

Taradi, S. K., Taradi, M., Radić, K., \& Pokrajac, N. (2005). Blending problem-based learning with web technology positively impacts student learning outcomes in acid-base physiology. Advances in Physiology Education, 29(1), 35-39.

Tarhan, L., \& Acar-Sesen, B. (2013). Problem based learning in acids and bases: Learning achievements and students' beliefs. J. of Baltic Science Educ., 12(5), 565-578.

Universitas Muhammadiyah Surakarta. (2010). SOP Proses Belajar Mengajar (Standard operating procedure of teaching and learning). Surakarta Indonesia.

van Rooij, S. W., \& Zirkle, K. (2016). Balancing pedagogy, student readiness and accessibility: A case study in collaborative online course development. The Internet and Higher Education, 28, 1-7. https://doi.org/10.1016/j.iheduc.2015.08.001.

Van Oostveen, R., Desjardins, F., \& Bullock, S. (2018). Professional development learning environments (PDLEs) embedded in a collaborative online learning environment (COLE): Moving towards a new conception of online professional learning. Education and Information Technologies, 1-38. https://doi.org/10.1007/s10639-018-9686-6.

Vidergor H.E., Krupnik-Gottlieb M. (2015) High order thinking, problem based and 
project based learning in blended learning environments. In H. E. Vidergor, \& C. R. Harris (Eds.), Applied practice for educators of gifted and able learners (pp. 217-232).. Rotterdam: SensePublishers.

Wahyudi, Sugiharto, B., \& Widoretno, S. (2015). Upaya meningkatkan kemampuan komunikasi oral siswa melalui penerapan model pembelajaran problem based instruction siswa kelas VII-A SMP Negeri 22 Surakarta tahun pelajaran 2012/2013 (Efforts to improve students' oral communication skills through the appli. Bio-Pedagogi, 4(1), 30-35.

Watkins, R., Leigh, D., \& Triner, D. (2004). Assessing readiness for e-learning. Performance Improvement Quarterly, 17(4), 66.

Wijaya, M. (2007). Pemanfaatan teknologi informasi dan komunikasi dalam pembelajaran (Utilization of information and communication technology in teaching and learning). Jurnal Pendidikan Penabur, 6(8), 50-59.

Wijsman, L. A., Saab, N., Schuitema, J., van Driel, J. H., \& Westenberg, P. M. (2019). Promoting performance and motivation through a combination of intrinsic motivation stimulation and an extrinsic incentive. Learning Environments Research, 22(1), 65-81. https://doi.org/10.1007/s10984-018-9267-z.

Winters, F. I., \& Alexander, P. A. (2010). Peer collaboration: The relation of regulatory behaviors to learning with hypermedia. Instructional Science, 39(4), 407-427.

Wood, D. F. (2003). Problem based learning. BMJ, 326, 328-330.

Xiong, Y., So, H.-J., \& Toh, Y. (2015). Assessing learners' perceived readiness for computer-supported collaborative learning (CSCL): A study on initial development and validation. Journal of Computing in Higher Education, 27(3), 215-239. https://doi.org/10.1007/s12528-015-9102-9.

Yang, N., Ghislandi, P., \& Dellantonio, S. (2018). Online collaboration in a large university class supports quality teaching. Educational Technology Research and Development, 66(3), 671-691. https://doi.org/10.1007/s11423-017-9564-8.

Yeh, Y. chu, \& Chu, L. H. (2018). The mediating role of self-regulation on harmonious passion, obsessive passion, and knowledge management in e-learning. Educational Technology Research and Development, 66(3), 615-637. https://doi.org/10.1007/s11423-017-9562-X.

Yew, E. H. J., \& Schmidt, H. G. (2011). What students learn in problem-based learning: a process analysis. Instructional Science, 40(2), 371-395. https://doi.org/10.1007/s11251-011-9181-6.

Zurita, G., Hasbun, B., Baloian, N., \& Jerez, O. (2015). A blended learning environment for enhancing meaningful learning using 21 st century skills. In G. Chen, V. Kumar, Kinshuk, R. Huang, \& S. C. Kong (Eds.), Emerging issues in smart learning. Lecture notes in educational technology (pp. 1-8). Heidelberg, Berlin: Springer. 